\title{
Agroindustry Development Policy: A Strategy towards Poverty
}

\section{Alleviation}

\author{
Muhammad Yamin ${ }^{1}$, M. Saleh S. Ali ${ }^{2}$, Rahman MI², Imam Mujahidin Fahmid ${ }^{3}$ \& Syahrumsyah Asri ${ }^{4}$ \\ ${ }^{1}$ Doctor Candidate, Agriculture Departement, Hasanuddin University, Makassar, 90245, South Sulawesi and \\ Institute of Research and Community Services, Tridharma University, Balikpapan, 76126, East Kalimantan, \\ Indonesia \\ 2 Professor, Department of Agriculture Socio-Economics, Faculty of Agriculture, Hasanuddin University, \\ Makassar, 90245, South Sulawesi, Indonesia \\ ${ }^{3}$ Senior Lecture, Department of Agriculture Socio-Economics, Faculty of Agriculture, Hasanuddin University, \\ Makassar, 90245, South Sulawesi, Indonesia \\ ${ }^{4}$ Senior Lecture, Board of Research \& Development of East Kalimantan, Samarinda, 75124, Indonesia \\ Correspondence: Muhammad Yamin, Agriculture Departement, Hasanuddin University, Makassar, 90245, South \\ Sulawesi, Indonesia. Tel: 62-81-4161-5307. E-mail: yamin090360@gmail.com; marwan_energy@yahoo.com
}

Received: January 12, 2018

Accepted: February 28, $2018 \quad$ Online Published: May 30, 2018

doi:10.5539/jsd.v11n3p258

URL: https://doi.org/10.5539/jsd.v11n3p258

\begin{abstract}
The aim of this research is to explain poverty alleviation program through agroindustry development policy in East Kalimantan Repoblic of Indonesia. The main contribution of this research is to developed a new strategy toward poverty alleviation. The method of study was used descriptive-case study method. The data used in this research was gathered from many sources such BPS (Statistic Central Bureau), East Kalimantan Yearly Report, East Kalimantan Base Data, and some informants at provincial level. The poverty data, financial budget agro industry development project data, financial budget accelerate poverty alleviation data, empowerment people data obtained was analyzed by using time series analysis. The result indicated that the agroindustry development policy reduced poverty level. Since 2006 to 2015 was achieved significantly result with average of $0,57 \%$ per year. On the other hand, the number could have be improved it when migretion to the area had been reduced as in the same period.
\end{abstract}

Keywords: Alleviation, Agroindustry, policy, poverty

\section{Introduction}

All economic development programs are directed to improve public welfare and specifically to reduce poverty. In Indonesia (White, 2011), many development programs have been implemented such Raskin (Rice for Poor), BLT (Direct Cash Support), PPK (Village Development Program), P2KP (Urban Poverty Program), PPIP (Empowerment Program for Rural Infrastructure), Program Keluarga Harapan (Family Hope Program), Micro Credit, KUR (People Business Credit) and many others to reduce poverty, but the poverty rate was still intolerable and up and down. In 1976, the number of population under poverty was 40 percent, but 20 years later, in 1996, it declined up to 11 percent(Asri.S, 2009), again in 2009, the poor population increased up to 32.53 million or 14.15 percent of total population. In 2010, poverty rate was expected to fall below $10 \%$. RPJMN (National Mid-Term Development Plan) 2010-2014 has sat up poverty rate reduction with 5 percent at the end of 2025, which is the end of Long Term Development period 2005-2025.

Previous studies on poverty reduction indicatedthat factors related to poverty eradication were (1) inflation; (2) price of food especially rice; (3) working condition of the poor in agricultural sector in rural areas; and (4) job opportunities in the informal sector, Smith(2011), Bass \& Dalal-Clayton(2012), Barrientos-Fuentes \& Berg (2013); Hajra \& Hajra (2015), and Rusdiansyah, (2013). Yunus in (Esty, 2011), Hulme, et al, (2012), Kwapong \& Hanisch, (2013), Collins, (2014) argued that an effort to reduce poverty is providing easy access to financial markat for the poor in order to gat working capital. In Indonesia this concept was implemented by establishing People's Business Credit (KUR=Kredit Usaha Rakyat) and micro credit, while in Bangladesh it was 
implemented by forming social businesses such as Grameen Bank, based on the teaching of Mahatma Gandhi, "swadeshi".

Basri Faisal, (2009), Mohd et al(2016),De Weerdt(2010),Pernia, (2010)Naseem(2012),Abubakar(2013),Nguyen et al (2016), Kuncoro(2006), pointed out that the success to reduce poverty in Cambodia, Vietnam, Laos, Tanzania, Kenya, Pakistan, Philippina and Latin America by implementing simple but humane economic approach by encouraging the real sector, production especially agriculture and light industry, besides providing aids for the poor who earn less than US \$ 1/capita/day. Similar to Kuncoro (2006), Bayaz Ozturk \& Macdonald (2016), Fahmid (2012) Adhikari (2013), M. R. Islam (2014), Anderson (2014), Daley \& Acker (2015) Arsyad, et al, (2015), Wymann von Dach, et al (2016) who found that developing small and household industries (IKRT) will benefit labor absorption and utilization of local natural resources, especially in rural areas6. The benefits of the labor absorption will lead to reduced poverty, equalized income distribution and developed rural economy.

Kuznats as statedin Kuncoro, (2006), Ofori-Boateng (2016), Zezza \& Tasciotti, (2010), Misturelli \& others (2010), Bruner (2012), Antonopoulos (2013), Wunder, et al, (2014), Saeed, et al (2015), Uisso \& Masao, (2016) argued that income inequality decreased along with increased of GNP per capita ("PDRB per capita" at regional level) in the next development stage. They mentioned that there were three factors causing poverty micro level to unequal distribution of resources ownership in the quality of human resources; and difference in capital access.

The representative of World Bank in Indonesia (2006) (as cited in Rusdiansyah (2013) statedthat nearly $42 \%$ of Indonesian people were live in the poverty line US \$ $1-2$. The World Bank recommended 3 (three) approaches to reduce poverty, i.e.; (1) creating economic growth, (2) creating social services and (3) making government regulation which benefit for the poor; in, Yusuf (2010), Hulme (2010) Grindle (2012), Pernia (2012), Guitart, et al (2012), Darkoh (2013), Makuwira (2013), Gebre, et al (2013), Brooks (2015), Mason (2015), Rivera (2015), and Cleofas (2016).

From 33 provinces In Indonesia in 2010, there were 17 provinces had poverty rate below the nationalaverage level and 16 provinces were above the nationalaverage, included Papua, West Sulawesi, Nangro Aceh Darussalam, etc (see. Figure1) Those provinces under nationalaverage level included DKI Jakarta, Bali, Bangka Belitung, East Kalimantan, South Kalimantan, Central Kalimantan, Banten etc.

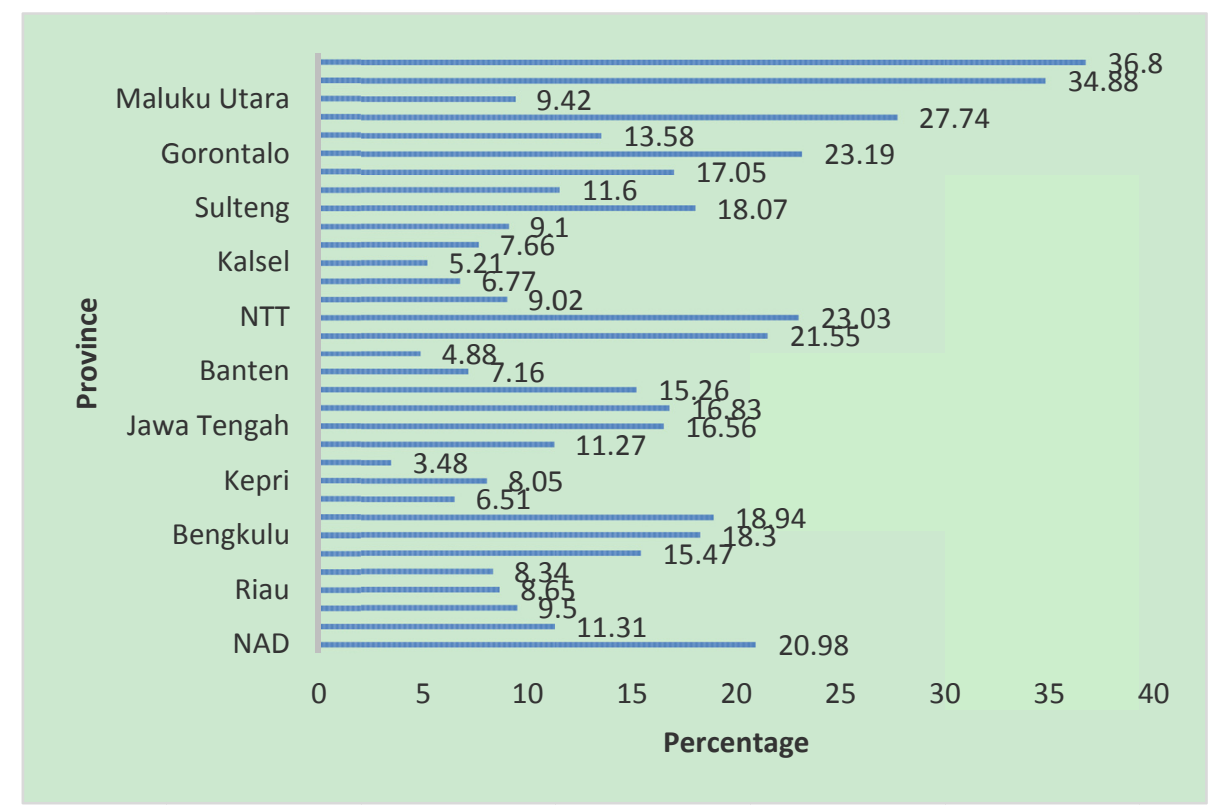

Figue 1. Poverty rate by Province, 2010

East Kalimantan as provinces belongs to above nationalaverage level had poor population around $7.66 \%$ or 243.000 people, Statistics Bureau (in indonesia BPS) (2010). (see. Figure 2) Although the number had declined, compared with other provinces in 2009 , the poverty rate was still relatively high but its position as the 7 th place in country poverty rate was not change. This means that there were fundamental problems in the development policy implemented by the East Kalimantan Provincial Government. 


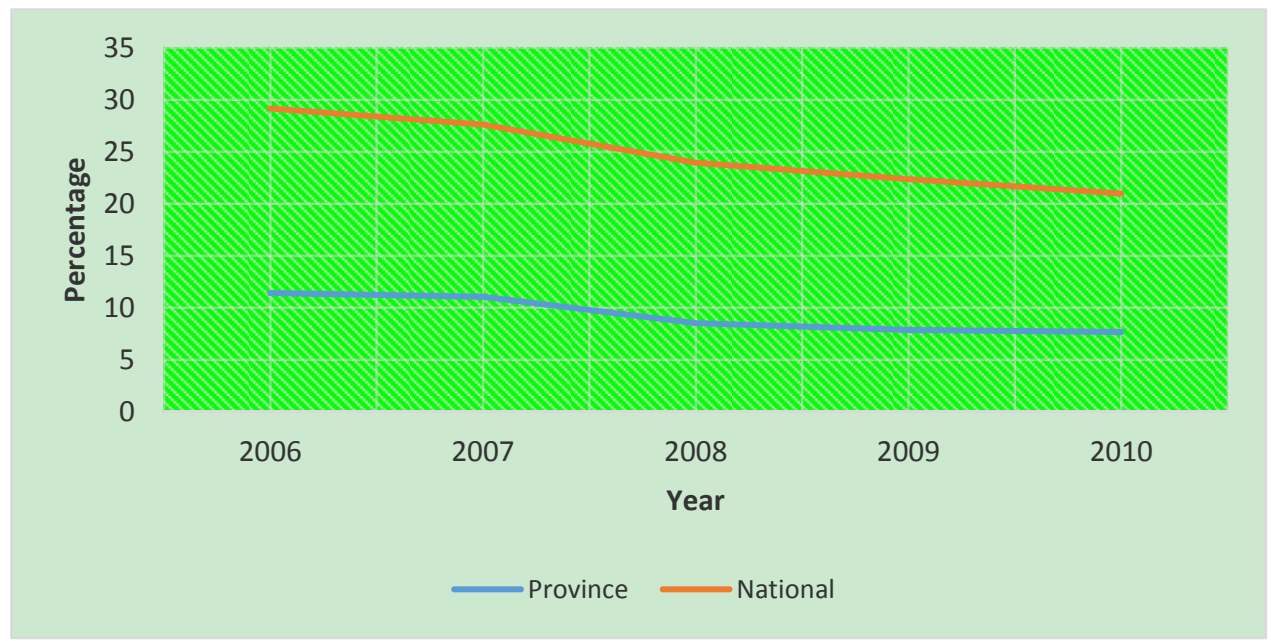

Figure 2. The relevance and effectiveness of the achievement of poverty alleviation programs in 2005-2010, compared to the nationalwith provinces

East Kalimantan has rich natural resources which have been exploited as a source of income for the APBD and in 2015 became the first rank as contributor for APBN. Although this province is a rich province but the incident of poverty is still high. Around 7\% of the population lives in poverty and most of them (62\%) live in rural area. This means that the exploitationof natural resources such as oil and gas, coal, gold, and forest did not brought welfare for the entire local socially; in,Campbell(2009), Boysen, et al (2016). Realizing this, since 2006 East Kalimantan Provincial Government has changed its development policies from being based on natural resources exploitationto agroindustry development as statedin its motto Kaltim Bangkit (Rise up East Kalimantan-(Governor Regulation, 2014 no: 18, 2015)

After around nine years, agroindustry development policy has brought significant changes to poverty rate in East Kalimantan. As of March 2015, total poor population in East Kalimantan decreased to 212,890 or around $6.23 \%$,Statistics Bureau East Kalimantan (in indonesia: BPS Kaltim, 2016) from 245,050 or around $7.86 \%$ in 2009 , or in other words poverty was reduced by $5.17 \%$ in 9 years, or $0.57 \%$ per year in average. The number could have be improved if migration to the area had been reduced as in the same period, pf or $46 \%$ of population growth in East Kalimantan was due to migration; in, Haysom (2010), Torres-Lima, et al (2010).

Based on transformation of natural base approach to agricultureindustrial base approach to guide development policy of East Kalimantan, the poverty rate in this province has declined significantly but but still high. This paper intended to explain how the agroindustry development policy implemented by East Kalimantan Provincial Government has contribution to reduced the poverty level.

\section{Method}

This research was conducted in East Kalimantan. This province was chosen because it was one of the rich province in Indonesia with regional budget of IDR 120,07 billion. The method of study was used descriptive-case study method. The data used in this research was gathered from many sources such BPS (Statistic Central Bureau), East Kalimantan Yearly Report, East Kalimantan Base Data, and some informants at provincial level. The poverty data, financial budget agro industry development project data, financial budget accelerate poverty alleviation data, empowerment people data obtained was analyzed by using time series analysis.

\section{Results}

\subsection{Poverty Defined}

Poverty is a complex phenomenon. It is usually defined in relation to income, often measured in terms of per capita gross domestic product (GDP). Extreme poverty is often defined as an income of less than $\$ 1$ per person per day in terms of purchasing power parity (PPP). Some researchers definepoverty as the lowest income quintile in a referenced population. Critics argue that measuring poverty in terms of GDP or PPP does not fully capture the phenomenon of poverty. A broader definition treats poverty as multidimensional, including (i) low income, (ii) low levels of education and health, (iii) vulnerability (to health or income loss, natural disaster, crime and violence, and education curtailment) and (iv) voicelessness and powerlessness (feeling discrimination, lacking 
income earning possibilities, mistreatment by state institutions, and lacking status under the law(World Bank, 2001) in Binswanger \& Landell-Mills, (2016). Many other indicators such as caloric intake and female literacy are also used. While measuring poverty in terms of income level may seem relatively straightforward, the multidimensional approach is more complex and involves factors that are difficult to quantify. To manage this complexity, researchers have developed indices, such as the UNDP Human Poverty Index, which conceives of poverty in terms of longevity, knowledge, and economic provisioning; in, Eric, et al(2003)

The concept of poverty is very diverse, ranging from mere inability to meat basic consumption needs and improve the situation, the lack of a level playing field, up to a broader sense to include the social and moral aspects. For example, there is the notion that poverty is associated with attitudes, cultural life, and the environment in a community or to that poverty is powerlessness group of people to a system that is implemented by a government that they are in a very weak position and exploited which is called as structural poverty; in, Suriansyah, et al (2014), D. Islam, et al (2016).

According to Nasikun (1995) in Suriansyah, et al (2014), Jindra \& Jindra (2016), poverty is a multifacated, multidimensional and integrated phenomenon. Being poor means not only living in conditions of shortage of food, clothing and shelter. Living in poverty often also means low access to a wide range of resources and assats which are very necessary to be able to obtain a means of meeting the life's most basic needs, such as: information,science, technology and capital. Moreover, living in poverty often also means living in alienation, with limited access to power and therefore of life choices narrow and stuffy.

Whereas Ravallion in (Fahmid, 2012), Suriansyah, et al (2014) and Arsyad et al., (2015), Belmonte-Martín \& Tufte (2016) stated: "poverty is hunger, not having residence, when gatting sick does nothave money for treatment. Poor people generally can not read because they were not able to go to school, do not have a job, afraid to face the future, loss of a child due to illness. Poverty also means powerlessness, marginalized and do not have a free taste in living life". In another opinion, the definition of poverty proposed by Mafruhah (2009) statedthat: "poverty is when people are in a condition that is very limited, both in accessibility to factors of production, business opportunities, education, other living facilities, so that in any business activity or be limited". From some of these opinions can be said that poverty describes the condition of the absence of ownership and low income, or in more datail describes a condition where ones can not be fulfilled their basic human needs, namely food, shelter, and clothing, etc.

People interpret and understand poverty differently. There are, therefore, different meanings attached to poverty and its impact on socially. What is important about these different meanings to poverty is that they all involve a common element of material insufficiency - especially the lack of resources needed for survival. Poverty studies and definitions thus lead to an identification of goods needed by human beings in order to keep on living. An important factor regarding the definition of poverty is the ability to function as a full and active member of the socially and have individual dignity, SPII, 2007:10 in Ramphoma (2014).

The considerationof poverty from a broader perspective is derived from a global acknowledgement that poverty is more than just having enough income to live by. It is now widely acknowledged that poverty is a multi-dimensional phenomenon which includes other essential dimensions of living standards. In addition to income and consumption, health and education are now part of the definition of poverty, Sabry (2009:48) in S. Ramphoma (2014).

Mokoena (2004:41), in S. Ramphoma (2014) points out that the defining poverty is a difficult task. Public and privateinitiatives, as well as the direction of policy regarding poverty alleviation, will all determine how poverty is defined - to answer the question, "Who is poor?" There are varying perspectives on what poverty is. There is a need to consider the factors discussed below when defining poverty

Generally, poverty is defined as an inability to access resources in order to enjoy a minimal or acceptable living; in, Mansur, et al (2013).This is in line with Black (2002) that poverty is defined as an inability to afford an adequate standard of consumption. On the other hand; in,Mansur, et al (2013), Ekasari, et al (2013) describes that poverty is concerned with case and generic theories of poverty. According to case theories of poverty, individuals who are unable to support themselves and to afford the basic needs without the assistance are considered living in poverty. For instance, older people, handicapped people, drug addicts and mentally ill persons are included among case-poverty. According to generic theories of poverty, poverty in explained by macro economy problems such as inadequate employment opportunities, low demand and low national income (less developed country). United Nation (UN) defined poverty as a denial of choices and opportunities, which is a violationof human dignity. In other words, it is suggested that people are poor due to lack of the basic capacity to participate effectively in socially. For instance, any person not having enough resources to feed a family, not 
having a school or clinic to go to, not having the land on which to grow one's food or a job to earn one's living and not having access to credit. United Nations Development Program (UNDP) describes poverty as a human condition characterized by sustained or chronic deprivation of the resources, capabilities, choices, security and power necessary for the enjoyment of an adequate standard of living and other civil, cultural, economic, political and social rights. Meanwhile, the World Bank (2011) suggests that poverty includes low incomes, the inability to acquire basic goods and services necessary for survival, low levels of health and education, poor access to clean water and sanitation, inadequate physical security, lack of voice and insufficient capacity and opportunity to batter one's life. In Malaysia, the definition of hard core poverty is whereby a household income is pf of the poverty line or less. The poverty line is the chosen minimum level of income or consumption, which any household income fallen below the minimum level is considered as poor. In other words, the critical threshold point represents the minimum "acceptable" income or consumption level at which individuals are able to achieve a minimum standard of living to maintain health and well-being. The definition of minimum standard is referred to the purchasing power parity (PPP) of those surveyed. However, the measurement to maintain the minimum "acceptable" standards of living normally varies from country to country. The concept of absolute poverty and hardcore poverty is used in the implementation of poverty eradication programs; in, Mat Zin (2011) in KM Mansur, et al (2013).

According to Millenium Development Goals (MDG's), one is called poor if he/she has income under $\$ 1.00$ per-day, The dollar value here is dollar value based on Purchasing Power Parity (PPP) which is converted with local currency based on prices in 1993; in, Mestrum (2005).

Statistics Bureau (in indonesia: BPS, 2010) uses the concept of the ability to meat basic needs (basic needs approach) to measure poverty.In this approach, poverty is viewed as economic inability to meatbasic food and non-food needs as measured from the expenditure aspect. This approach calculates Headcount Index, which is the percentage of poor population to total population.

Poverty in this study is defined as a condition where there is shortage of common possessions such as food, clothes, shelter and drinking water, or things tightly related to quality of life, so one doesn't receive proper respect as a citizen. Poverty is understood as lack of income, lack of materials, whather clothes, food or shelter and social isolation (inability to participate in the socially).

\subsection{Development Vision of East Kalimantan}

East Kalimantan province has an abundant of natural resources and make this province as a rich province. This situation should have significant impacts on East Kalimantan population. Considering the current potentials and condition of East Kalimantan and in an attempt to fulfill people's aspirations on pledges through the motto, "Kaltim Bangkit" (Rise-up of East Kalimantan), to achieve the vision of East Kalimantan Development, namely: "Realizing East Kalimantan as the Leading Centre of Agroindustry and Energy toward Just and Prosperous Socially".

As the implementationof the vision above, the development missions of East Kalimantan province include: Realizing competitive and pro-democracy economic system in sustainable development manner; revitalizing agriculture in general by using natural resources optimally and sustainably by implementing naturalresources utilization regulations, rehabilitation and reforestation of critical lands; increasing investment using regulations which guarantee easiness of running businesses and increasing investment promotions; identifying business opportunities based on natural resources; increasing oil and gas and non-oil and gas exports and decreasing oil and gas and non-oil and gas imports; improving and empowering the economy of the community; managing cultural and historical wealth and other tourism potentials as sources of foreign exchange; and reinforcing the utilization of Regional Spatial Plan of East Kalimantan Province.

East Kalimantan Provincial Government implements development strategy which prioritizes on 3 aspects, i.e.: 1). Infrastructure development, 2). Agricultural development in general and 3). Human resources development; which is directed to: 1). Create safe, democratic and peaceful East Kalimantan which is supported by a clean and dignified government, 2). Realizecompetitive and pro-democracy local economy by:(a). Increase fulfillment of basic infrastructures to provide access for all activities to stimulate people to become independent to improve the standard of living, (b) Improve people's welfare by reliable economy based on agribusiness and ecotourism and (c) Create well-preserved nature by reinforcing regulations of land and natural resources utilization and coordination of regional spatial plan. 3). Improving the quality of human resources and people welfare by: (a) Improving the quality of human resources of East Kalimantan, so that they have mental, spiritual and physical resilience to participate and be competitive in every field at national and international levels. (b) Improving community service and empowerment, thus reducing poverty rate and (c) Making transmigration areas as key 
agricultural areas which can contribute to physically and spiritually prosperous socially.

\subsection{Poverty Reduction Program}

Various poverty reduction programs have been implemented in East Kalimantan such as agroindustry development programs to develop the potential of rural agroindustry to improve the added value of agricultural products by developing agricultural facilities and infrastructures, making cooperatives and agricultural product businesses and developing rural transportations. There are also household agroindustry programs to develop household agroindustry to increase diversification of agroindustry products to open new job opportunities. There is also revitalization of agricultural businesses to improve agricultural job opportunities in potential rural areas to open access to agricultural businesses in rural areas by providing rural infrastructures, assisting and counseling agriculture, aiding production facilities, supporting marketing access of agricultural products and other programs.

\subsection{Results of PovertyAlleviation Program}

Total poor population in East had decreased significantly every year. In 2006 , total people living in poverty were $335,400(11.41 \%)$, in 2007 it was 324,800 (11.04\%), in 2008 it was 259,450 (8.53\%), in 2009 it was 245,050 (7.86\%) and in 2010, based on BPS of East Kalimantan, it was 243,000 (7.66\%). For details, see Figure 3.

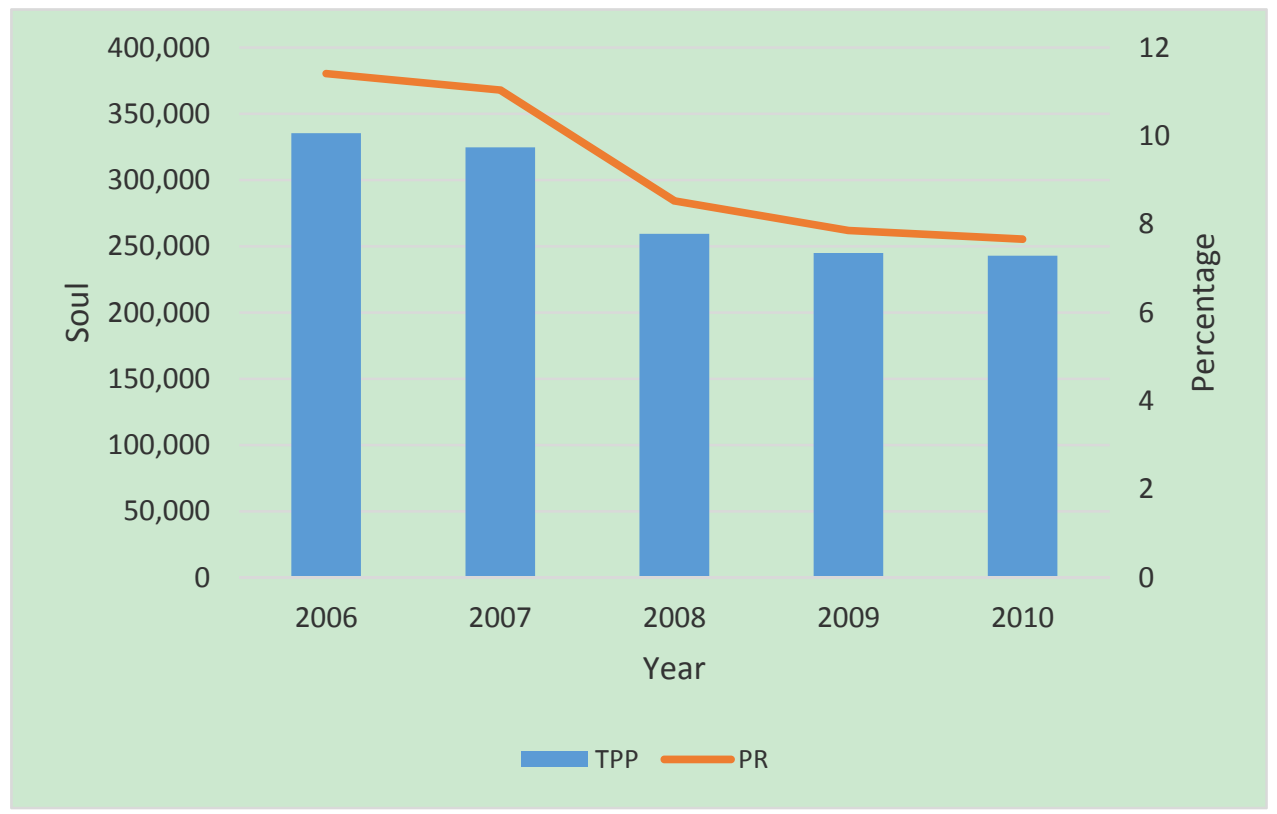

Figure 3. Total poor population and poverty ratein East Kalimantan in $2006-2010$

This condition is inseparable from population growth due to migrants who come to this region as a consequence of the autonomy era as regions which offer job opportunities and income become migrants' destination. It's due to a large portion of migration to look (46.7\%).

Population growth in East Kalimantan as of 2010 was high, $3.81 \%$, and still higher than the national average. See Figure4; 


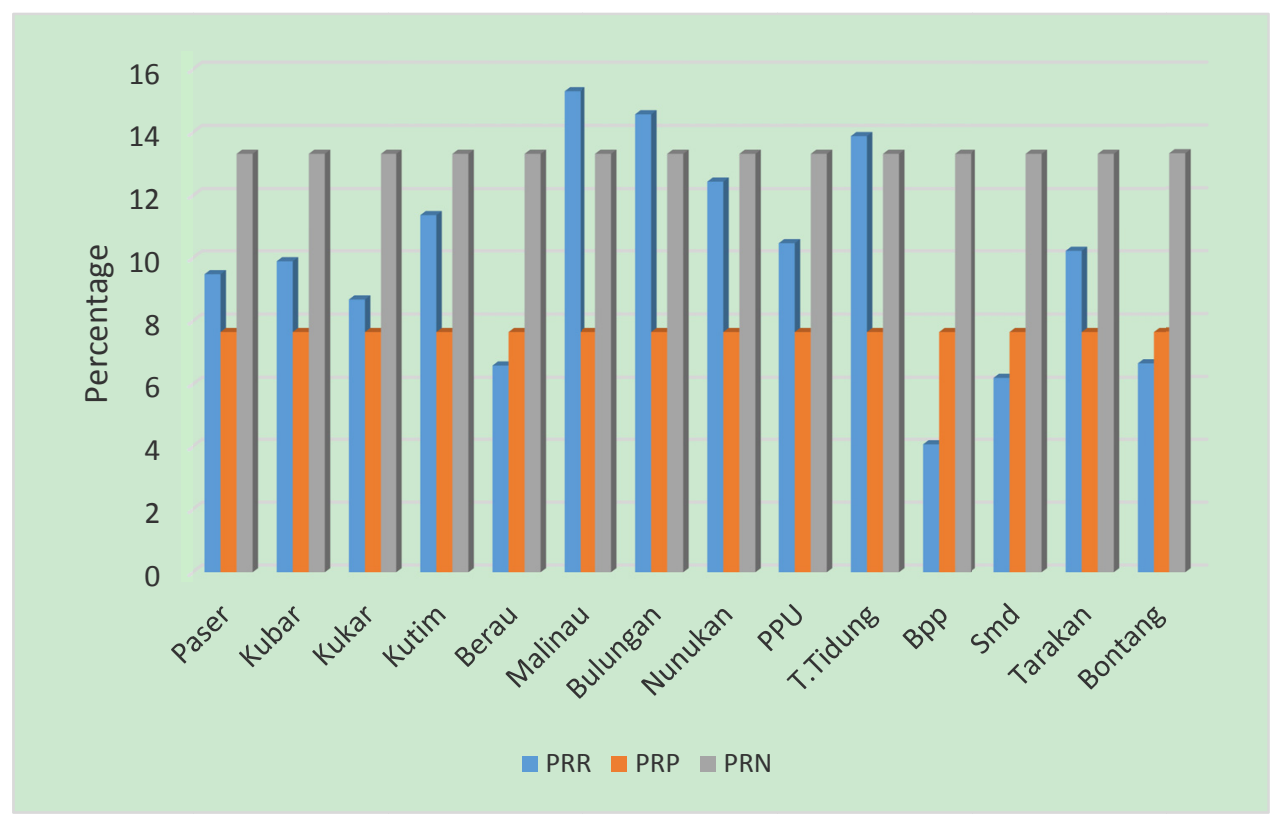

Figure 4. Poverty rate by regency/city and provincial and national averages, 2010

Based on this tendency, the most influential factor for the growth of the poor population is migration from other regions as regencies/cities with high population of people living in poverty are open areas and autonomous regions which donot have good population management. Balikpapan in particular has very good population management but still has migration problem, especially those passing through because Balikpapan is the gate to East Kalimantan. However, overall poverty rate in East Kalimantan since 2006 to 2009 declined and nationally East Kalimantan is in the $5^{\text {th }}$ (fifth) place in least total poor population.

Poverty issue isn't only about the number and percentage of the poor. Other dimensions which should be considered are gap and severity of the poverty. Beside reducing the number of the poor, poverty reduction policies should also reduce the gap and severity of poverty. The Gap Index (P1) and Severity Index (P2) of Poverty in East Kalimantan in 2007 - 2010 are shown in Figure5.

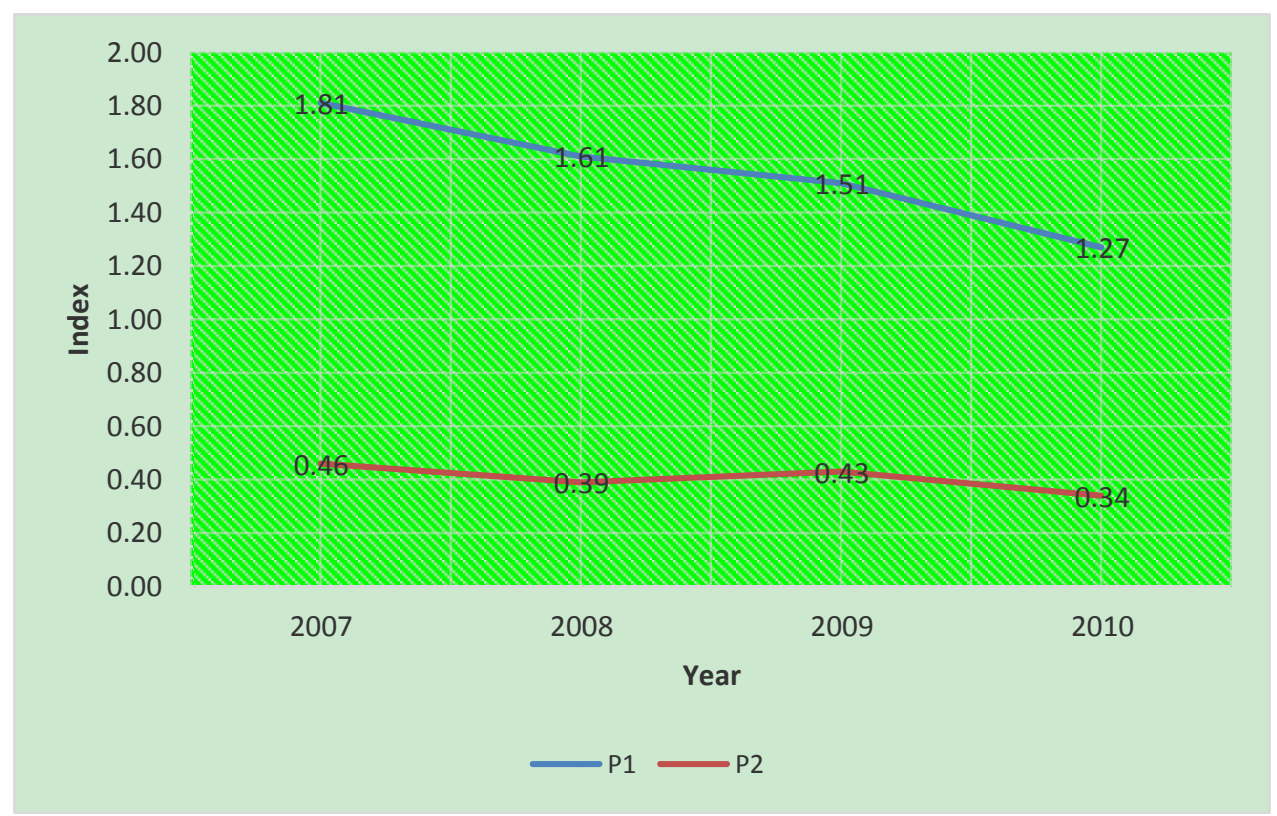

Figure 5. Gap index (P1) and severity index (P2) of poverty in $2007-2010$

In March 2010-March 2011 period, Poverty Gap Index $\left(\left(\mathrm{P}_{1}\right)\right.$ tended to decline and Poverty Severity Index $\left.\left(\mathrm{P}_{2}\right)\right)$ 
also tended to decline. Poverty Gap Index declined from 1,273 on March 2010 to 0,921 on March 2011. The decline of the poverty gap index indicated that average expenditure of the poor approached the poverty line. The Poverty Severity Index also declined from 0,339 to 0,228 in the same period. The decline of the poverty severity index showed reduction of the imbalance of the expenditure of the poor.

The values of Poverty Gap Index $\left(\mathrm{P}_{1}\right)$ and Poverty Severity Index $\left(\mathrm{P}_{2}\right)$ in rural areas were higher than in urban areas. On March 2011, the value of the Poverty Gap Index $\left(\mathrm{P}_{1}\right)$ for urban areas was 0,658 , while in rural areas it was 1,352 . The value of Poverty Severity Index $\left(P_{2}\right)$ for urban areas was 0,190 , while in rural areas it was 0,289 (see Table 1). It was concluded that poverty rate in rural areas is worse than in urban areas.

Table 1. Poverty gap index $\left(\mathrm{P}_{1}\right)$ and poverty severity index $\left(\mathrm{P}_{2}\right)$ of East KalimantanMarch 2010-March 2011

\begin{tabular}{lccl}
\hline Year & Urban & Rural & Urban + Rural \\
\hline Poverty Gap index (P1) & & & \\
\hline March 2010 & 0.566 & 2.436 & 1.273 \\
March 2011 & 0.658 & 1.352 & 0.921 \\
\hline Poverty Severity Index (P2) & & & \\
\hline March 2010 & 0.122 & 0.696 & 0.339 \\
March 2011 & 0.190 & 0.289 & 0.228 \\
\hline
\end{tabular}

Source: BPS-East Kalimantan, 2011

By region, poor population was mostly located in rural areas with a percentage of 62.84 percent, and the rest was in urban areas (37.16\%). The poor population in rural areas on March 2010 was 11.21 percent, lower than March 2011 which was 13.66 percent. In other words, in the period, total poor population in rural areas decreased by 7.99 thousand people. While in urban areas, it was 4.06 percent, higher than March 2010 which was 4.02 percent or increased by 12.9 thousand people.

Total poor population in East Kalimantan on March 2011 was 247,900 increasing by 2.02 percent compared with total poor population on March 2010 which was 243,000. For details, see table 2. Total and Percentage of Poor Population in East Kalimantan on March 2010 - March 2011.

Table 2. Total and percentage of poor population in East Kalimantan March 2010 - March 2011

\begin{tabular}{lllllll}
\hline & \multicolumn{2}{l}{ Total of Poor Population (.000) } & \multicolumn{3}{l}{ Percentage of Poor Population (\%) } \\
\hline Year & City & Rural & City + Rural & City & Rural & City + Rural \\
\hline March 2010 & 79,24 & 163,76 & 243,00 & 4.02 & 13.66 & 7.66 \\
March 2011 & 92,14 & 155,77 & 247,90 & 4.06 & 11.21 & 6.77 \\
\hline
\end{tabular}

Source: BPS-East Kalimantan, 2011

The population of the poor is influenced by Poverty Line because the poor are people who have average expenditure per capita per month under the Poverty Line.

On March 2010 - March 2011, the Poverty Line increased by 11.08 percent, from IDR 285,218 per capita per month on March 2010 to IDR 316,819 per capita per month on March 2011. Considering the components of the Poverty line (GK), which consist of Food Poverty Line (GKM) and Non-Food Poverty Line (GKNM), it's evident that the role of food commodities is bigger than non-food commodities (housing, clothes, education, and health). On March 2011, the contribution of GKM to GK in urban areas was 70.19 percent, while in rural areas the contribution of GKM to GK was 74.29 percent.

The poverty life in urban areas was higher than in rural areas. On March 2011, the poverty line in urban areas was IDR 339,392, while in rural areas it was IDR 279,920. (see table 3. The Poverty Line of East Kalimantan on March 2010 to March 2011). It showed thatmeeting life necessities in urban areas was more-costly than in rural areas. 
Table 3. The poverty line of East Kalimantan March 2010 - March 2011

\begin{tabular}{llll}
\hline \multicolumn{4}{c}{ Poverty Line (Rp/capita/month) } \\
\hline Area / Year & Food & Non Food & Total \\
\hline Urban & & & \\
\hline March 2010 & 216,067 & 91,412 & 307,479 \\
March 2011 & 238,231 & 101,161 & 339,392 \\
\hline Rural & & \\
\hline March 2010 & 184,942 & 63,641 & 248,583 \\
March 2011 & 207,941 & 71,979 & 279,920 \\
\hline
\end{tabular}

Source: BPS-East Kalimantan, 2011

Poverty alleviation policies in East Kalimantan realized through 3 programs or 73activities which divided in three major groups namely: agroindustry, accelerating poverty alleviation and support/empowerment.

If these programs progress was observed in the last 5 years and turns out that agroindustry development gives a significant impact on poverty in East Kalimantan, This can be shown in figure 6.

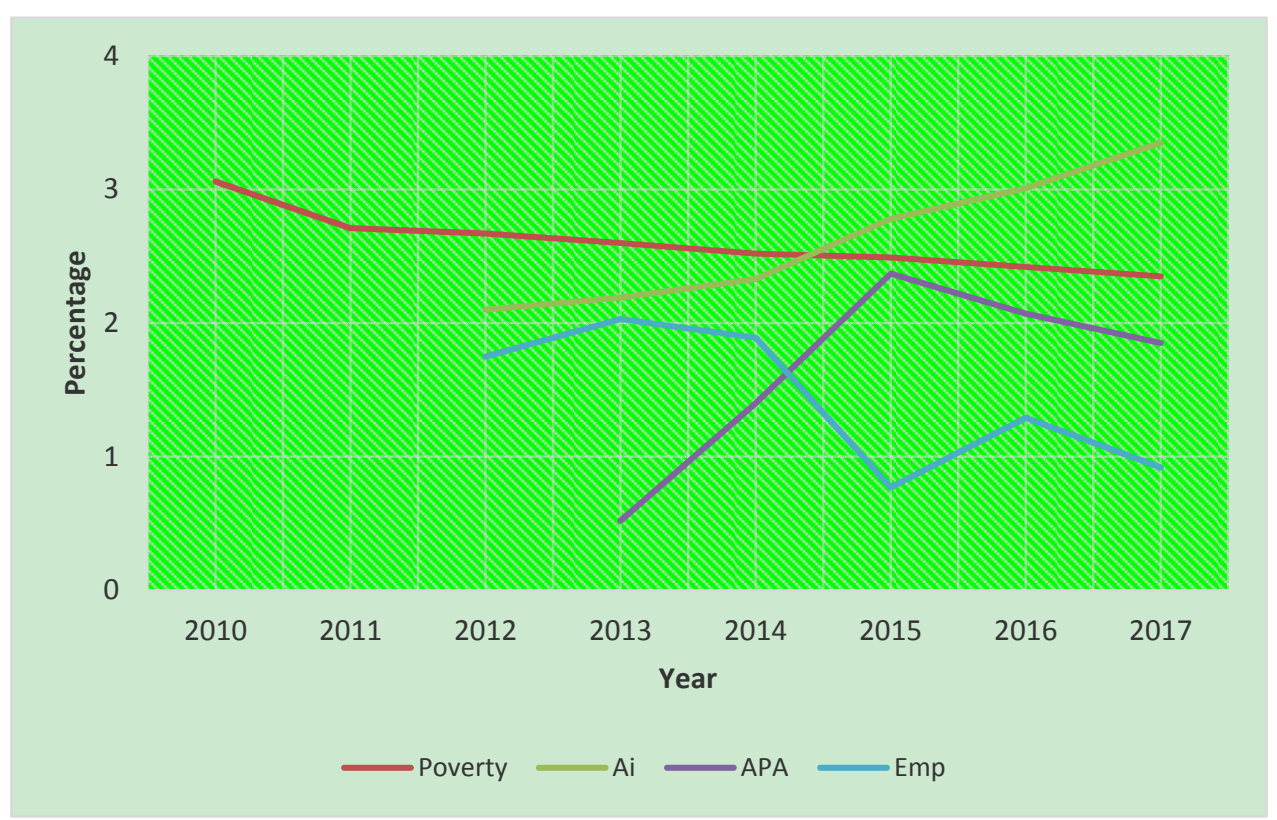

Figure 6. Relationship between growth agroindustry with poverty reduction

Blue color showed that poverty numbers decrease since 2010 until 2016 while agroindustry that marked by red color showed increase along with a decrease in poverty, whilst accelerating of countermeasures of poverty and empowerment assistance which marked by green color and light green color did not show significant graphic of the decreasing of poverty.

\section{Conclusion}

Therefore, in 2009, a reformation was started through the motto: Rise up East Kalimantan (Kaltim Bangkit) which means changing development policies which used to be oriented to mining and forestry natural resources exploitation to agroindustry development. After ten years, the agro-industry policy implemented by the provincial government of East Kalimantan brought a significant result on poverty alleviation. The poor population of East Kalimantan on March 2015 had declined to $6.23 \%$ from $11.41 \%$ or had declined by $5.17 \%$ in ten years which an average decline of $0.57 \%$ per year.

\section{Acknowledgements}

This research was funded by the provincial government of East Kalimantan, Indonesia. 


\section{References}

Abubakar, B. M. (2013). Poverty alleviation through strategic public library services in Nigeria in the $21 \mathrm{st}$ century: a model. IFLA journal, 39(1), 4-14. https://doi.org/10.1177/0340035212472283

Adhikari, B. (2013). Poverty reduction through promoting alternative livelihoods: implications for marginal drylands. Journal of International Development, 25(7), 947-967. https://doi.org/10.1002/jid.1820

Anderson, T. (2014). Does the extension of the rural road network have a positive impact on poverty reduction and resilience for the rural areas served? If so how, and if not why not?

Antonopoulos, R. (2013). Expanding Social Protection in Developing Countries: A Gender Perspective. Levy Economics Institute at Bard College Working Paper, (757).

Arsyad, M., Nuddin, A., Zamhuri, M. Y., \& Yusuf, S. (2015). The Poverty Reality of Coastal and Agriculture: How Severe the Seaweed Farmers and Cocoa Smallholders Are? International Journal of Agriculture System, 2(2), 119-131.

Asri.S. (2009). Policies and Strategies for Poverty Reduction in East Kalimantan Province (in indonesia: Kebijakan dan Strategi Penanggulangan Kemiskinan di Provinsi Kalimantan Timur (Pertama). Bekasi, Jakarta: Sinar Ilmu.

Basri Faisal. (2009). Notes of a Decade of Crisis; Transformation of Structural Problems, and Indonesia's Economic Expectations (in Indonesia: Catatan Satu Dekade Krisis; Transformasi Masalah Struktural, dan Harapan Ekonomi Indonesia). Jakarta: Erlangga.

Bass, S., \& Dalal-Clayton, B. (2012). Sustainable development strategies: a resource book. Routledge.

Bayaz Ozturk, G., \& Macdonald, S. P. (2016). Intertemporal Poverty among Older Americans. Journal of Poverty, 1-21.

Belmonte-Martín, I., \& Tufte, G. C. (2016). Spain's and Norway's Welfare Regimes Compared: An Outcome-based Evaluation of how Welfare Regimes Influence the Risk of Poverty and Social Exclusion. Journal of Poverty, 1-16.

Binswanger, H. P., \& Landell-Mills, P. (2016). The World Bank's strategy for reducing poverty and hunger: a report to the development community. Washington DC: World Bank. Retrieved from https://vtechworks.lib.vt.edu/handle/10919/65983

Boysen, O., Jensen, H. G., \& Matthews, A. (2016). Impact of EU agricultural policy on developing countries: A Uganda case study. The Journal of International Trade \& Economic Development, 25(3), $377-402$. https://doi.org/10.1080/09638199.2015.1069884

BPS. (2010). East Kalimantan in The Data. the Central Board of Statistics.

Brooks, S. M. (2015). Social Protection for the Poorest TheAdoption of Antipoverty Cash Transfer Programs in the Global South. Politics \&Socially, 43(4), 551-582. https://doi.org/10.1177/0032329215602894

Bruner, J. L. (2012). Is Poverty Reduction Enough? In Learning and Doing Policy Analysis in Education (p. 1340). Springer. https://doi.org/10.1007/978-94-6091-933-6_2

Campbell, B. (2009). Mining in Africa: regulation and development. IDRC.

Cleofas, J. A. (2016). Virtue Athics, Situationism, and the Filipino Business Leader's Compassion for the Poor. Journal of Catholic Social Thought, 13(1), 103-118. https://doi.org/10.5840/jcathsoc201613118

Collins, C. S. (2014). RATRACTED ARTICLE: Can funding for university partnerships between Africa and the US contribute to social development and poverty reduction? Higher Education, 68(6), 943-958. https://doi.org/10.1007/s10734-014-9753-x

Daley, B., \& Acker, W. (2015). A Horizon Scan of Environmental Drivers of Poverty.

Darkoh, M. B. K. (2013). Social and Environmental Science Research in Support of a Policy Definition of the "Future We Want"in Africa. Development, 56(3), 387-395. https://doi.org/10.1057/dev.2014.3

De Weerdt, J. (2010). Moving out of poverty in Tanzania: Evidence from Kagera. The Journal of Development Studies, 46(2), 331-349. https://doi.org/10.1080/00220380902974393

Ekasari, Z. K., Saleh, S. A. M., Jusoff, K., Salman, D., Akhsan, A., Kasirang, A., ... Fudjaja, L. (2013). Communication Pattern and Conflict in Agricultural Extension. Asian Social Science, 9(5), 27. https://doi.org/10.5539/ass.v9n5p27 
Eric, C., Chatwynd, F., \& Spector, B. (2003). Corruption and Poverty: A review of recent literature. Management Systems International, Washington, DC, USA.

Esty, K. (2011). Lessons from Muhammad Yunus and the Grameen Bank. OD Pract, 43(1), 24-28.

Fahmid, I. M. (2012).Identity In Power (in Indonesia: Identitas Dalam Kekuasaan). Makassar: Ininnawa.

Gebre, A., Belay, S., \& Kloos, H. (2013). Food insecurity, poverty, and HIV/AIDS. In Vulnerabilities, impacts, and responses to HIV/AIDS in Sub-Saharan Africa (p. 84-104). Springer.

Governor Regulation, 2014 no: 18. (2015). The work plan of development of the east Kalimantan Province. East Kalimantan Governor.

Grindle, M. (2012). Good governance: The inflation of an idea. Planning ideas that matter, 259-282.

Guitart, D., Pickering, C., \& Byrne, J. (2012). Past results and future directions in urban community gardens research. Urban Forestry \& Urban Greening, 11(4), 364-373. https://doi.org/10.1016/j.ufug.2012.06.007

Hajra, C., \& Hajra, J, (2015). Ineffectiveness of poverty alleviation programmes in underdeveloped economies: a theoretical analysis.

Haysom, G. (2010). Urban agriculture in the city of Cape Town. Sustaining Cape Town: Imagining a Livable City. Stellenbosch: African Sun Media, 211-226.

Hulme, D. (2010). Global poverty: How global governance is failing the poor (Vol. 44). Routledge.

Hulme, D., Hanlon, J., \& Barrientos, A. (2012). Just give money to the poor: The development revolution from the global South. Kumarian Press.

Islam, D., Sayeed, J., \& Hossain, N. (2016). On Daterminants of Poverty and Inequality in Bangladesh. Journal of Poverty, 1-20.

Islam, M. R. (2014). Improving Development Ownership Among Vulnerable People: Cplenges of NGOs' Community Empowerment Projects in Bangladesh. Asian Social Work and Policy Review, 8(3), 193-209. https://doi.org/10.1111/aswp.12035

Jindra, I. W., \& Jindra, M. (2016). Connecting Poverty, Culture, and Cognition: The Bridges Out of Poverty Process. Journal of Poverty, 1-23.

Kourilsky, P. (2012). Altruity: Key to the fight against poverty. Field Actions Science Reports. The journal of field actions (Special Issue 4).

Kuncoro, M. (2006). Ekonomika Pembangunan: Teori Masalah dan Kebijakan (4 ${ }^{\text {th }}$ ed.). Yogyakarta: UPP STIM YKPN, Ed.4.

Kwapong, N. A., \& Hanisch, M. (2013). Cooperatives and Poverty Reduction: A Literature Review. Journal of Rural Cooperation, 41(2).

Makuwira, J. J. (2013). Non-governmental development organizations and the poverty reduction agenda: the moral crusaders. Routledge.

Mansur, K. M. et al. (2013). A STUDY ON POVERTY CONCEPTS AND PERSPECTIVES: CONCEPTUAL PAPER. BIMP - EAGA Journal for Sustainable Tourism Development., Volume 1. Diambil dari. https://sites.google.com/site/journalsustainablatourism/2013-v1n1-Paper06.pdf

Mason, G. (2015). Strategies for the integration of poverty alleviation into management curriculum. Responsible Management Education and the Cplenge of Poverty: A Teaching Perspective, 78.

Mestrum, F. (2005). Poverty reduction and sustainable development. In The World Summit on Sustainable Development (p. 35-55). Springer. Diambil dari http://link.springer.com/chapter/10.1007/1-4020-3653-1_2

Misturelli, F., \& others. (2010). What does it mean to be poor? Framing differences and implications for development initiatives. CAB Reviews: Perspectives in Agriculture, Vaterinary Science, Nutrition and Natural Resources, 5(025), 1-10. https://doi.org/10.1079/PAVSNNR20105025

Mohd, S., Senadjki, A., \& Mansor, N. (2016). Trend of Poverty among Elderly: Evidence from Household Income Surveys. Journal of Poverty, 1-19.

Naseem, S. M. (2012). A Review of Studies on Poverty in Pakistan: Origin, Evolution, Thematic. Pakistan Institute of Development Economics, Islamabad, Pakistan.

Nguyen, K. A. T., Jolly, C. M., Bui, C. N., \& Le, T. T. (2016). Aquaculture and poverty alleviation in Ben Tre 
Province, Vietnam. Aquaculture Economics \& Management, 20(1), 82-108. https://doi.org/10.1080/13657305.2016.1124938

Ofori-Boateng, K. (2016). Analysis of Severity of Poverty and Social Cohesion among the Urban Poor Migrants in Ghana. Journal of Poverty, 1-23.

Pernia, E. M. (2010). (DP 2006-02) Diaspora, Remittances, and Poverty in RP's Regions. UPSE Discussion Papers.

Pernia, E. M. (2012). Is labor export good development policy? Philippine Review of Economics, 48(1), 13-34.

Ramphoma, S. (2014). Understanding poverty: causes, effects and characteristics. Interim: Interdisciplinary Journal, 13(2), 59-72.

Rivera, J. P. R. (2015). A Repeated Cross-Section and Pseudo Panel Analysis of Alleviating Poverty in Developing Economies: The Philippine Case 1. Journal of Economics and Economic Education Research, $16(1), 235$.

Saeed, A., ul Hassan, M., Atta, G., \& others. (2015). The Politics of Poverty Reduction Strategy Papers. Journal of Political Studies, 22(2), 495.

Smith, T. (2011). Using critical systems thinking to foster an integrated approach to sustainability: A proposal for development practitioners. Environment, development and sustainability, 13(1), 1-17. https://doi.org/10.1007/s10668-010-9243-y

Suriansyah, S. Z., Muluk, K., Idris, A., \& others. (2014). Poverty Reduction Policy Evaluation: A Study of Independent Village Development Movement (Gerakan Pembangunan Desa Mandiri, Gerbang Dema) in Respen Tubu Village of Malinau Regency-East Kalimantan Province of Indonesia. www.iiste.org, Vol.4,. Diambil dari https://www.mysciencework.com/publication/show/adb03290ad49a494424203355cf6ea3b

Torres-Lima, P., Chávez-Muñoz, A., Ávila-Jiménez, G., \& Contreras-Prado, S. (2010). Urban agriculture as a part of a sustainable matropolitan development program: A case study in Mexico City. Field Actions Science Reports. The journal of field actions (Special Issue 1).

Uisso, A. J., \& Masao, C. A. (2016). Women participation in agroforestry farming system: A strategy towards poverty reduction in Morogoro rural district, Tanzania. Athiopian Journal of Environmental Studies and Management, 9(5), 613. https://doi.org/10.4314/ejesm.v9i5.8

White, S. (2011). Government decentralization in the 21st century. A report of the CSIS program on crisis, conflicts, and cooperation. Centre for Strategic and International studies.

Wunder, S., Angelsen, A., \& Belcher, B. (2014). Forests, livelihoods, and conservation: broadening the empirical base. World Development, 64, S1-S11. https://doi.org/10.1016/j.worlddev.2014.03.007

Wymann von Dach, S., Höggel, U., \& Kakridi Enz, F. (2016). Compensation for Ecosystem Services (CES): A Catalyst for Ecosystem Conservation and Poverty Alleviation?

Yusuf, M. (2010). Community targating for poverty reduction: Lessons from developing countries. The Pardee Papers $N, 8$.

Zezza, A., \& Tasciotti, L. (2010). Urban agriculture, poverty, and food security: Empirical evidence from a sample of developing countries. Food policy, 35(4), 265-273. https://doi.org/10.1016/j.foodpol.2010.04.007

\section{Copyrights}

Copyright for this article is retained by the author(s), with first publication rights granted to the journal.

This is an open-access article distributed under the terms and conditions of the Creative Commons Attribution license (http://creativecommons.org/licenses/by/4.0/). 